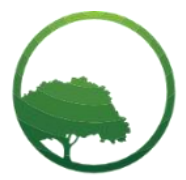

Business \& Social Science IJRBS

\section{Research in Business \& Social Science}

\section{IJRBS VOL 10 NO 5 ISSN: 2147-4478}

Available online at www.ssbfnet.com Journal homepage: https://www.ssbfnet.com/ojs/index.php/ijrbs

\title{
The influence factors of tax avoidance in Indonesia
}

\author{
(D) Rosida Ibrahim ${ }^{(a) *(D)}$ Sutrisno T. ${ }^{(b)}$ (iD) M. Khoiru Rusydi ${ }^{(c)}$ \\ ${ }^{(a, b, c)}$ Accounting Department, Faculty of Economics and Business, University of Brawijaya Jl. MT. Haryono No.165, Malang, Indonesia
}

A R T I C L E I N F O
Article history:
Received 12 June 2021
Received in rev. form 13 July 2021
Accepted 17 July 2021
Keywords:
Executive characteristics, family
ownership, tax avoidance, political
connections
introduction
JEL Classification:
O15

\begin{abstract}
A B S T R A C T
This study aims to analyze the effect of executive characteristics and family ownership as a stimulus factor for tax avoidance and to see the existence of a political relationship as a moderating variable in the effect of executive characteristics and family ownership on tax avoidance. This research was conducted on manufacturing companies listed on the Indonesia Stock Exchange during 2017-2019. In this study, the sample was determined based on the purposive sampling technique with the criteria that the sample company was a manufacture listed on the IDX for three consecutive years from 2017-2019, published an annual report in the 2017-2019 period sequentially, did not experience delisting, was not a company the IPO in 2018-2019, did not experience any losses and did not have an ETR value of more than 1. The research sample was obtained as many as 138 companies with 3 years of observation. This study uses multiple linear regression analysis (Multiple Regression Analysis) and Moderate Regression Analysis (MRA) using the Statistical Product and Service Solution (SPSS) program. The results showed (I) executive characteristics had a significant positive effect on tax avoidance (II) family ownership had a significant negative effect on tax avoidance (III) political connections were not able to strengthen the executive's positive influence on tax avoidance (IV) political connections weakened family ownership on tax avoidance. This study can also show that the sample companies tend to comply with tax rules, they avoid sanctions and fines and consider the risk of loss that must be faced by the company when proven to do tax avoidance.
\end{abstract}

(C) 2021 by the authors. Licensee SSBFNET, Istanbul, Turkey. This article is an open access article distributed under the terms and conditions of the Creative Commons Attribution (CC BY) license (http://creativecommons.org/licenses/by/4.0/).

\section{Introduction}

The government continues to increase the potential for state revenue because taxes are considered the main source of state revenue to meet state expenditure needs. However, companies have a different view on taxes. Taxes are considered by many companies as a large cost without making a direct contribution as well as reducing the availability of corporate cash flows (Chen et al., 2010). Companies will try to pay less tax or pay nothing at all. Efforts made by the company to minimize the tax expense through tax avoidance.

In Indonesia, one indication of tax avoidance is evidenced by the low level of tax compliance seen from the current tax ratio (Rusydi \& Martani, 2014). Based on data from the Ministry of Finance, Indonesia's 2017-2019 tax ratio values were 10.7\%, 11.5\%, and $10.7 \%$, respectively. The current state of Indonesia's tax ratio, when compared to other Asian countries, is still said to be below. According to Organization for Economic Cooperation and Development (OECD) data, Malaysia's tax ratio in 2017 was $13.6 \%$, Singapore $14.1 \%$, Philippines $17.5 \%$, and Thailand 17.6\% (Cnbcindonesia, 2019).

The case that occurred at PT Adaro Energy Tbk in 2019 provides another piece of evidence that many companies in Indonesia still do tax avoidance. PT Adaro Energi is suspected of evading tax of 125 million dollars through the transfer pricing method against a subsidiary in Singapore in the 2009-2017 fiscal year (Tirto, 2019). Another case occurred in 2010 where PT Kaltim Prima Coal, PT Bumi Resources, and PT Arutmin were found to have tax evasion amounting to Rp 1.5 trillion, Rp 376 billion, and US\$27.5 million in the 2008-2010 fiscal year (Berisatu, 2010).

* Corresponding author. ORCID ID: 0000-0002-2519-1793

(C) 2021 by the authors. Hosting by SSBFNET. Peer review under responsibility of Center for Strategic Studies in Business and Finance. https://doi.org/10.20525/ijrbs.v10i5.1295 
Tax avoidance by companies is inseparable from decisions made by executives. Certain characteristics carried out by the executive will affect the decisions they make (Low, 2009). The more risk-taking an executive is, the more daring he is to do tax avoidance (Pitaloka \& Merkusiwati, 2019; Carolina et al, 2014). The results of other studies are certainly different, that an executive has not dared to do tax avoidance because the principal still has a big influence in making company decisions (Kartana \& Wulandari, 2018).

Tax avoidance is also related to the company's ownership structure. The structure in question is the family ownership structure of the company. Shareholdings are concentrated in large numbers and family involvement in management influences corporate tax policy (Gaaya et al., 2017). The results of the research by Kovermann \& Wendt (2019) show that companies with family ownership tend to avoid tax because the family will get large profits at the expense of other parties. Other studies show different results that companies with family ownership tend to be less tax aggressive (Chen et al., 2010).

Variations in the results of research on executive characteristics and family ownership on tax avoidance can be influenced by the existence of political connections owned by the company. Political connections are considered a valuable resource for companies that can provide special facilities (Fisman, 2001). Political connections provide advantages in terms of lower detection by authorities, information about future regulatory changes, and insurance coverage for risky actions (Kim \& Zang, 2014). The profits obtained by the company by forming political connections become an incentive for companies to be more daring to take risky decisions, including in managing corporate taxes.

The results of the research of Mirza et al, (2019) and Wu et al, (2012) show that directors with political ties have many advantages in terms of taxation, thus encouraging them to be bolder in taking risky decisions such as tax avoidance. The results of Hidayati \& Diyanti (2018) also show that political connections make families more aggressive in terms of taxation. Families will take advantage of the low detection risk and fines to maximize their profits.

The inconsistency of the results of previous studies motivated researchers to review the effect of executive characteristics and family ownership on tax avoidance by adding political connections as a moderating variable. Another motivation for this study is the use of different measures of the variables of family ownership and political connections from previous studies. In this study, family ownership will be measured by comparing the number of shares owned by the family traced through the ultimate approach with all outstanding shares of the company. Political connections in this study are measured based on research by Supatmi et al, (2019) which assesses political connections based on structural government positions with the status of Civil Servants in Indonesia.

\section{Literature Review}

\section{Theoretical Background}

\section{Agency theory}

Type I agency conflict occurs when there is a contract between the principal as the employer and the agent as the party who is hired to carry out the company's activities and is authorized to make the best decisions for the company (Jansen \& Meckling, 1976). This relationship can lead to agency conflicts when there is information asymmetry and conflicts of interest. Tax avoidance decisions made by the executive contain an agency conflict in it. Often the executive will prioritize himself over the interests of the principal.

Type I, agency conflict as described by Jensen and Mackling (1976) is less common in firms with family ownership. Agency problems are more common in type II, namely between the majority shareholder or the controlling party and the minority shareholder or noncontrolling party (Desai \& Dharmapala, 2006). The controlling party has a much greater opportunity to carry out a takeover at the expense of the non-controlling party. The existence of significant control rights makes the family have a great opportunity to do tax avoidance. Tax avoidance is expected to provide a larger stored cash flow for the family and can hide from other parties losses due to expropriation (Kovermann \& Wandt, 2019).

\section{Resource dependent theory}

Resource dependence theory views the company as an open organizational system that depends on the external environment. This dependence will lead to risk and uncertainty which will ultimately affect organizational behavior (Hilman, 2005). The company will try to manage the problem of dependence on external parties by preparing various strategies to create a favorable environment for the company. Hilman et al., (2009) argue that overcoming dependency problems can be done by conducting inter-organizational relationships such as mergers, joint ventures, boards of directors, political actions, and executive succession.

One important source of interdependence and business uncertainty is the government because it will always be influenced by various decision-makers. One way to connect companies with the government is through the appointment of directors or boards of commissioners who have political ties (Hilman et al., 2009). It is hoped that establishing a relationship with the government, can create a favorable environment for companies such as the ease of obtaining unique information about policies, having a wide political/bureaucratic access network, and gaining access and influence in policymaking (Hilman, 2005). The existence of these advantages motivates companies to be more daring to take risky actions such as tax avoidance. 


\section{Executive characteristics and tax avoidance}

This tax avoidance policy is not intentional but created by the executives of the company. The character of each executive will affect the direction of corporate decision-making, including tax avoidance (Novita, 2016). Executives with risk-taking characteristics will be more willing to take big risks in making business decisions than executives who avoid risk (Low, 2006). Executive risk-takers believe that the higher the risk in the business, the higher the returns will be.

The results of research by Butje \& Tjondro (2014); Pitaloka \& Merkusiwati (2019) show that executive characteristics affect tax avoidance. The more executives take risks, the higher the executive's courage to do tax evasion. When executives decide to tax avoidance, the company's risk of detection and fines is much greater. However, executives hope that by avoiding taxation they can maximize their profits without paying attention to the risks that will be accepted by the owners of the company. In line with the agency theory that an executive as an agent will tend to maximize his interests rather than the interests of the principal (Jensen \& Mackling, 1976). Based on the explanation and previous research, the following hypothesis is proposed:

\section{H1: Executive characteristics have a positive effect on tax avoidance}

\section{Family ownership and tax avoidance}

Companies with family ownership have characteristics that can affect the nature and level of corporate tax treatment. The family as the majority shareholder has significant control over the company. A significant position in the company is often used by families to increase their profits at the expense of others (Gaaya et al., 2019). Family involvement in the board of directors or top management is intended to increase control and control rights in the company (Chu, 2011). Directors from families tend to make decisions by prioritizing their interests. Thus, the existence of these characteristics provides a great opportunity for companies with family ownership to avoid tax.

The results of research by Kovermann \& Wendt (2019); Sari \& Martani, (2010); Wirawan \& Sukharta, (2018) show that companies with family ownership tend to be more tax aggressive. Families with greater control over the company provide opportunities for them to avoid taxes and enjoy greater benefits in the form of cash flow and make it easier for families to manipulate and take over (Desai \& Dharmapala, 2006). This is in line with type II agency theory which states that the controlling party tends to maximize the interests of its group by sacrificing or usurping the rights of other (non-controlling) parties. Based on the explanation and previous research, the following hypothesis is proposed:

\section{H2: Family ownership has a positive effect on tax avoidance}

\section{Political connection on executive characteristics and tax avoidance}

Executives with risk-taking characters tend to be more willing to take big risks in making business decisions, one of which is tax avoidance. Executives who are risk-takers expect maximum profits for themselves and ignore the risk of large fines decreased transparency of financial statements, and reduced investors (Butje \& Tjondro, 2014). The executive's courage to take risky actions is not only motivated by the many benefits offered, but also by political connections (Ding et al., 2015).

The political connections possessed by the executive provide access to support and protection by the government against corporate budgetary constraints such as obtaining bank loans, low-interest rates, bailouts, and tax subsidies (Faccio et al., 2006). Resource dependence theory explains that the political ties of the board of directors give them greater access and control over external resources so that it will support high-risk decision-making (Peng \& Lou, 2000). In line with the results of research by Ding et al, (2015); Mirza et al, (2019) show that directors with political ties are more willing to take risky actions because they can rely on government support in the event of investment failure. Thus, there is a potential for political connections to strengthen executives to be more willing to take risks, such as tax avoidance. Based on the explanation and previous research, the following hypothesis is proposed:

\section{H3: Political relations strengthen the positive effect of executive characteristics on tax avoidance}

\section{Political connections to family ownership and tax avoidance}

Many companies establish relationships with the government because political connections are considered to provide convenience in transactions and provide preferential treatment to companies (Fisman, 2001). The family as the controlling shareholder tends to form political relations to increase their economic interests (Haque et al., 2011). Companies will try their best to take advantage of proximity to the government to get more convenience and benefits, including in terms of taxation (Pranoto \& Widagdo, 2016).

The results of Hidayati \& Diyanti (2018) provide evidence that political connections encourage families to be more tax aggressive. Families seek to take advantage of proximity to the government to reduce the risk of detection and fines for aggressive taxation. Reducing the costs of tax evasion provides families with greater incentives and benefits, especially since the family is in control of the company. This is in line with the resource dependence theory which states that the political ties formed by the company provide a more favorable environment for the company (Hilman et al., 2009). Thus, it can be seen that there is a potential political connection to strengthen companies with family ownership to do tax avoidance. Based on the explanation and previous research, the following hypothesis is proposed: 
H4: Political relations strengthen the positive influence of family ownership on tax avoidance

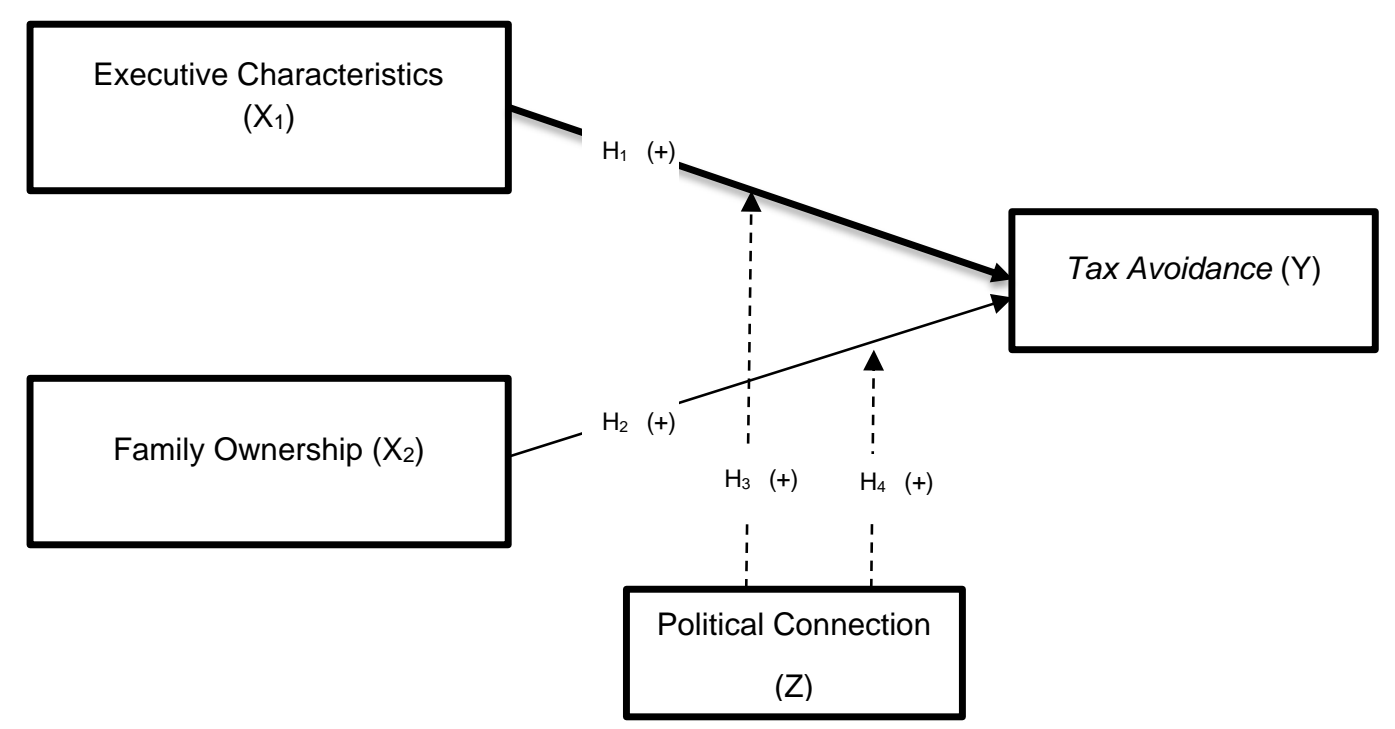

Figure 1: Research Conceptual Framework

\section{Research and Methodology}

This study uses a quantitative approach with the type of research based on associative research objectives or causal relationships. The population of this study is all manufacturing companies listed on the Indonesia Stock Exchange in 2017-2019. The sample was determined based on the purposive sampling technique with the criteria presented in table 1 as follows:

Table 1: Sample Selection Procedure

\begin{tabular}{|c|c|c|}
\hline No & Criteria & Total \\
\hline 1 & Manufacturing companies are listed on the IDX consecutively from 2017 to 2019 & 191 \\
\hline 2 & Companies that do not publish consecutive annual reports during 2017-2019 & $(14)$ \\
\hline 3 & Companies experiencing delisting in 2017-2019 & (6) \\
\hline 4 & Company IPO in 2018-2019 & $(28)$ \\
\hline 5 & Companies that suffer losses & $(51)$ \\
\hline 6 & Value of Effective Tax Rate (ETR) $>1$ & (2) \\
\hline 7 & Outliers & $(44)$ \\
\hline \multicolumn{2}{|c|}{ Number of companies used as research samples } & 46 \\
\hline \multicolumn{2}{|c|}{ Number of observations for 3 years $(2017-2019)$} & 138 \\
\hline
\end{tabular}

Source: Primary Data (2019)

Data Analysis Technique

This study uses multiple linear regression analysis (Multiple Regression Analysis) and Moderated Regression Analysis (MRA) using the Statistical Product And Service Solution (SPSS) program. The empirical model of the research regression equation is as follows:

The regression model uses ETR in measuring tax avoidance

$$
\begin{gathered}
E T R=\alpha+\beta_{1} R I S K+\beta_{2} K K+\beta_{3} R O A+\beta_{4} S I Z E+\beta_{5} P P E+\varepsilon \\
E T R=\alpha+\beta_{6} R I S K+\beta_{7} K K+\beta_{8} K P+\beta_{9} R O A+\beta_{10} S I Z E+\beta_{11} P P E+\varepsilon \\
E T R=\alpha+\beta_{12} R I S K+\beta_{13} K K+\beta_{14} K P+\beta_{15} K P * R I S K+\beta_{16} K P * K K+\beta_{17} R O A+\beta_{18} S I Z E+\beta_{19} P P E+\varepsilon
\end{gathered}
$$


The regression model uses CETR in measuring tax avoidance

$$
\begin{gathered}
C E T R=\alpha+\beta_{20} R I S K+\beta_{21} K K+\beta_{22} R O A+\beta_{23} S I Z E+\beta_{24} P P E+\varepsilon \\
C E T R=\alpha+\beta_{25} R I S K+\beta_{26} K K+\beta_{27} K P+\beta_{28} R O A+\beta_{29} S I Z E+\beta_{30} P P E+\varepsilon \\
C E T R=\alpha+\beta_{31} R I S K+\beta_{32} K K+\beta_{33} K P+\beta_{34} K P * R I S K+\beta_{35} K P * K K+\beta_{36} R O A+\beta_{37} S I Z E+\beta_{38} P P E+\varepsilon
\end{gathered}
$$

\section{The regression model uses BTD in measuring tax avoidance}

$$
\begin{gathered}
B T D=\alpha+\beta_{39} R I S K+\beta_{40} K K+\beta_{41} R O A+\beta_{42} S I Z E+\beta_{43} P P E+\varepsilon \\
B T D=\alpha+\beta_{44} R I S K+\beta_{45} K K+\beta_{46} K P+\beta_{47} R O A+\beta_{48} S I Z E+\beta_{49} P P E+\varepsilon \\
B T D=\alpha+\beta_{50} R I S K+\beta_{51} K K+\beta_{52} K P+\beta_{53} K P * R I S K+\beta_{54} K P * K K+\beta_{55} R O A+\beta_{56} S I Z E+\beta_{57} P P E+\varepsilon
\end{gathered}
$$

ETR : Tax avoidance measured using the Effective Tax Rate

CETR : Tax avoidance as measured using the Cash Effective Tax Rate

BTD : Tax avoidance as measured using Book-Tax Difference

$\beta_{1}, \ldots . ., \beta_{57}:$ Regression Coefficient

$\alpha \quad:$ Constant

RISK : Executive Characteristics

KK : Family Ownership

KP : Political Connection

ROA : Return on Assets

SIZE : Company Size

PPE: Property, Plant, and Equipment or fixed assets

$\varepsilon$ : Error term

\section{Variables}

\section{Tax Avoidance}

Tax avoidance is measured using the Effective Tax Rate (ETR), Cash Effective Tax Rate (CETR), and Book-tax Difference (BTD). ETR is measured by dividing current tax expense by profit before tax. The lower the ETR indicates the higher the company's tendency to do tax avoidance and otherwise. CETR is measured by dividing the amount of cash paid for taxes by profit before taxes. The lower the CETR indicates the higher the company's tendency to do tax avoidance and otherwise. BTD is measured by looking at the difference in the amount of profit calculated based on account with the amount of profit calculated based on taxes on total assets. The greater the difference between accounting profit and taxable profit, the greater the tendency to do tax avoidance.

\section{Executive Characteristics}

The characteristics of an executive are assessed by looking at how much risk the company has. The company's own risk is measured by the standard deviation of EBITDA divided by total assets (Butje \& Tjondro, 2014). The higher the risk of the company indicates that an executive is a risk-taker, conversely the lower the risk of the company indicates that the executive tends to risk reverse.

\section{Family Ownership}

Family ownership is traced using the ultimate approach, namely tracing company ownership directly or indirectly (Siregar, 2011). A company is said to be a family-owned company if more than $20 \%$ of the shares are owned by the family. Individuals can be called family if they have the same last name or there are ties of marriage, children, and siblings (La Porta et al., 1999). Measurement of family ownership in the company is done by dividing the number of shares owned by each shareholder by the total outstanding shares of the company (Kovermann \& Wendt, 2019). 


\section{Political Connection}

A company is said to have political relations if there is at least one of the 20 largest shareholders or leaders of the company who currently or has served as a government official, TNI/Polri, and leader of a political party, then at least there are family members who have ties to the company. with the president or former presidents (Faccio, 2006); Wong \& Hooy, 2018). The measurement of political connections was carried out concerning the research of Supatmi et al., (2019) which assessed political connections based on structural government positions with the status of Civil Servants in Indonesia.

\section{Control Variable}

The control variable in this study is the Return on Assets (ROA) which is measured using the profit after tax formula divided by the total assets of the previous year. The next control variable is company size (SIZE) which is measured by performing the natural logarithm of the company's total assets. The last control variable is Property, Plant, and Equipment (PPE), or the company's fixed assets as measured by the natural logarithm of the company's fixed assets.

\section{Result and Discussions}

\section{Descriptive Statistics Results}

Descriptive statistics in this study provide an overview of research data related to drinking value, maximum value, average, and standard deviation. The results of descriptive statistics are presented in table 2.

Table 2: Descriptive Statistics

\begin{tabular}{lllll}
\hline Variable & Minimum & Maximum & Average & $\begin{array}{l}\text { Standard } \\
\text { Deviation }\end{array}$ \\
\hline ETR & 0,110 & 0,371 & 0,252 & 0,050 \\
\hline CETR & 0,033 & 0,581 & 0,278 & 0,108 \\
\hline BTD & $-0,086$ & 0,022 & $-0,029$ & 0,024 \\
\hline RISK & 0.362 & 2.232 & 0.934 & 0,428 \\
\hline RK & 0.000 & 0,991 & 0,366 & 0,332 \\
\hline SIZE & 0.009 & 0,165 & 0,071 & 0,037 \\
\hline PPE & 25,796 & 32,201 & 28,792 & 1,530 \\
\hline KP & 0.050 & 1,000 & 0,467 & 0,166 \\
\hline SOur: & 0,000 & 3,850 & 1,128 & 1,254 \\
\hline
\end{tabular}

Source: Primary Data (2019)

\section{Hypothesis testing}

The model in this study has met the requirements of normality, heteroscedasticity, and multicollinearity tests. The regression results are presented in Table 3 .

Table 3: Regression Test Results

\begin{tabular}{lllll}
\hline Variable & Hypothesis & Coefficient & CETR \\
\cline { 3 - 5 } & & ETR & $-0,075^{*}$ & BTD \\
\hline RISK & H1 & $-0,026^{*}$ & 0,011 & $0,015^{* *}$ \\
\hline KK & H2 & $0,022^{*}$ & $-0,032$ & $-0,005$ \\
\hline KP*RIKS & H3 & $-0,014$ & 0,006 & $0,000^{*}$ \\
\hline KP*KK & H4 & $0,033^{* *}$ & $-1,375^{* *}$ & $-0,018$ \\
\hline ROA & & $-0,253$ & 0,003 & $-0,189^{*}$ \\
\hline SIZE & $-0,006^{*}$ & $-0,044$ & 0,001 \\
\hline PPE & & $-0,028$ & $2,576^{*}$ & 0,017 \\
\hline F value & & $2,803^{*}$ & 0,054 & $12,803^{* *}$ \\
\hline Adj. $\boldsymbol{R}^{2}$ & & 0,062 & & 0,301 \\
\hline
\end{tabular}

* significance at level $5 \%$,** significance at level $1 \%$

Variable definition

$\mathrm{ETR}=$ Effective Tax Rate $;$ CETR = Cash Effective Tax Rate $; \mathrm{BTD}=$ Book-Tax Defference $;$ RISK= Company Risk $; \mathrm{KK}=$ Family Ownership ; KP= Political Connection ; ROA=Return On Assets; $\mathrm{SIZE}=$ Company Size $; \mathrm{PPE}=$ Property, plant and Equipment Source: Primary Data (2019)

The t-test results presented in Table 3 show that in the ETR measurement method the executive characteristic variable has a coefficient value of -0.026 with a $5 \%$ significance level of 0.043 . In the CETR measurement method, the coefficient of executive characteristics is -0.075 with a $5 \%$ significance level of 0.012 . In the BTD measurement method, executive characteristics have a coefficient value of 0.015 with a $1 \%$ significance level of 0.009 . When the coefficient value is negative to ETR and CETR, the value 
of tax avoidance increases, then when the coefficient value is positive to BTD, the value of tax avoidance increases. Thus, it can be concluded that executive characteristics have a positive effect on tax avoidance and H1 is accepted.

In the ETR measurement method, the family ownership variable has a coefficient value of 0.022 with a $5 \%$ significance level of 0.045. A positive coefficient value on the ETR indicates that the lower the tax avoidance is carried out. The CETR measurement method shows that family ownership has a coefficient value of 0.11 and is not significant. The BTD measurement method also shows that family ownership has a coefficient value of -0.005 and is not significant. Thus, it can be concluded that family ownership is detrimental to tax avoidance on the ETR measurement method and family ownership has no effect on tax avoidance on the CETR measurement method and BTD or $\mathrm{H} 2$ is rejected.

The interaction between political connection variables and executive characteristics in the ETR measurement method has a coefficient value of -0.014 and is not significant. In the CETR measurement method, the interaction between political connection variables and executive characteristics has a coefficient value of -0.032 and is not significant. The same result is shown in the BTD measurement method that the interaction of the two variables has a coefficient value of 0.000 and is not significant. Thus, it can be concluded that political connections are not able to strengthen the positive influence of executive characteristics on tax avoidance or $\mathrm{H} 3$ is rejected.

The interaction between the variables of political connection and family ownership in the ETR measurement method has a coefficient value of 0.033 and is not significant. The CETR measurement method shows the interaction of the two variables has a coefficient value of 0.006 and is not significant. In the BTD measurement method, the interaction of political connections and family ownership has a coefficient value of -0.018 and a $1 \%$ significance level of 0.00 . This shows that political connections are not able to strengthen the positive effect of family ownership on tax avoidance in the ETR and CETR methods. On the other hand, political connections weaken the positive effect of family ownership on tax avoidance in the BTD method. Thus it can be concluded that H4 is rejected.

Control variables with a significance value $<0.05$ are Return On Assets (ROA) and firm size (SIZE). The ROA coefficient value is 1.375 on the CETR method and the coefficient value of -0.189 on the BTD method. SIZE has a coefficient value of -0.066 in the ETR measurement method. This shows that both ROA and SIZE have a positive effect on tax avoidance.

\section{Discussion}

\section{Executive characteristics and tax avoidance}

The results of this study indicate that $\mathrm{H} 1$ is accepted or the characteristics possessed by executives can increase their courage in tax evasion. The results of this study are in line with research conducted by Butje \& Tjondro (2014); Pitaloka \& Merkusiwati (2019) which shows that executive characteristics have a positive effect on tax avoidance. The more executives take risks, the greater the executive's courage to take risky actions such as tax evasion. Executives dare to take huge risks for tax evasion to maximize their profits.

The results of this study support agency theory which explains that an executive as an agent has the responsibility to manage and make the best policies to optimize the interests of company owners (Jensen \& Meckling, 1976). However, often the existence of asymmetric information and conflicts of interest make decisions taken by the executive according to their interests. Executives tend to act risky to get maximum profit and ignore the losses that will be borne by the owner of the company such as doing tax evasion.

\section{Family ownership and tax avoidance}

The results of this study do not support H2 which discusses that family ownership will increase tax avoidance. The results of the hypothesis indicate that family ownership has a significant negative effect on tax avoidance on the ETR measurement method and there is no effect of family ownership on tax avoidance on the CETR and BTD methods.

The results of this study are in line with research conducted by Chen et al, (2010); Maharani \& Juliarto (2019) which shows that family companies have a low tendency to avoid tax. Families tend to obey and maintain the good name of the company for the survival of the company in the future. On the other hand, this study does not support the type II agency theory which states that the majority shareholder as the controlling party of the company has the opportunity to maximize their interests. The majority party does not care about the interests of the minority and tends to sacrifice the interests of other parties.

If the research results are related to current conditions, it shows that the government has carried out supervision and regulation of income taxes related to related party transactions that have special relationships in UU No. 36 of 2008 Article 18 paragraph 3. Supervision is tightened again with PMK No. 213 of 2016 and POJK No 42 of 2020 which requires taxpayers to organize and store documents or information related to transactions with related parties. Thus, there are very few opportunities for taxpayers, especially companies with family ownership, to tax avoidance.

\section{Political connection on executive characteristics and tax avoidance}

The results of this study do not support $\mathrm{H} 3$ which discusses that political connections can strengthen executives to be more daring to do tax avoidance. The results of the hypothesis indicate that the interaction between the political relationship variable and the executive characteristic variable on tax avoidance in the ETR, CETR, and BTD methods has insignificant results. This shows that 
the existence of political connections in the executive is not able to influence the executive to be bolder in carrying out tax avoidance actions.

The results of this study do not support the resource dependence theory which states that uncertainty in the external environment, one of which is the government, can be reduced by establishing a political mechanism owned by company board members (Hilman et al., 2009). The company appoints directors or commissioners who have political ties with the aim of providing a more conducive environment. On the other hand, this study is in line with the research results of Jian et al, (2012); Lestari, (2017) which states that executives with political ties tend not to do tax evasion. The government tends to give stricter supervision to executives who have political ties, so they are more obedient and more careful in making business decisions.

The government has regulated the problem of calculating taxes related to related transactions in UU No. 36 of 2008 article 18 paragraph 3 concerning income tax, PMK No. 213 of 2016, and POJK No. 42 of 2020. The amount of supervision from various parties makes executives have different goals in taking advantage of their closeness to the government. Executives view that closeness to the government is no longer to reduce the detrimental impact of tax avoidance but to increase the value of the company.

\section{Political connections to family ownership and tax avoidance}

The results of this study do not support $\mathrm{H} 4$ which discusses that political connections can strengthen families to be more daring to do tax avoidance. The results of the hypothesis show that the interaction of political connection variables and family ownership has a significant positive effect on tax avoidance in the ETR and BTD models and the interaction between political connection variables and family ownership has no effect on tax avoidance in the CETR model. The results on the ETR and BTD models show that political connections weaken firms with family ownership to evade tax. The results of the CETR model show that the existence of political connections is not one of the factors stimulus companies with family ownership to avoid tax.

The results of this study do not support the resource dependence theory which states that the political ties formed by companies aim to overcome dependence on an uncertain external environment, one of which is the government (Hilman et al., 2009). The company hopes that by establishing a relationship with the government, it can benefit from changes in the information on tax regulations and lower control over tax matters. On the other hand, the results of this study are in line with research conducted by Bimo et al, (2019) which explains that the existence of political connections does not make families dare to do tax evasion. Families prefer to comply with taxes and avoid sanctions and fines. Families tend to take advantage of their proximity to the government to improve company performance which will have an impact on increasing the reputation and survival of the company going forward.

The inability of political connections to encourage families to be more daring to do tax avoidance is also supported by the results of data analysis of sample companies. The sample companies show a low tendency to do tax avoidance. Sample companies tend to be tax compliant. Supervision has also been carried out by various parties by issuing UU No. 36 of 2008 article 18 paragraph 3 concerning income tax, PMK No. 213 of 2016, and POJK No. 42 of 2020 to regulate income tax issues related to related parties.

\section{Conclusion}

Based on the previous discussion, it can be concluded that the manufacturing companies on the Indonesia Stock Exchange which are the samples of this study have a low tendency to carry out tax avoidance. Sample companies tend to be obedient taxpayers so they do not dare to do tax avoidance. This study succeeded in proving that executive characteristics are the driving factors for companies to be more daring to do tax avoidance. Different evidence is obtained that family ownership is not a stimulus factor for companies to dare to do tax avoidance.

This study also failed to provide evidence that the existence of political connections as a reinforcement of executive characteristics and family ownership further increases tax avoidance. The existence of political connections makes the company not do tax avoidance. Given the sample companies tend to have complied with tax regulations. The sample companies avoid sanctions and fines if they are proven to have violated tax provisions. The sample company also considers the risk of loss that the company must face when it is proven to have committed tax avoidance.

This study has limitations in the process of data collection and analysis. Some companies cannot be traced to final ownership to the individual level through the company's annual report because of the limited information on the company's shareholdings presented. Thus, it is not known whether the company is a family company or not.

Based on the limitations that have been described, suggestions that can be given by researchers for future researchers are that researchers can consider using other data sources besides the annual financial statements in tracing the final ownership of the company. Further researchers can use other databases such as OSIRIS and ORBIS in the hope of obtaining complete information about the research data.

\section{References}

Beritasatu.com. (2010, November 23). Empat kasus pajak besar: Grup Bakrie. Retrieved from BeritaSatu: https://www.beritasatu.com/ekonomi/10707/empat-kasus-pajak-besar-grup-bakrie. 
Bimo, I. D., Prasetyo, C. Y., \& Susilandari, C. A. (2019). The effect of internal control on tax avoidance: the case of Indonesia. Journal of Economics and Development, 21(2), 131-143. doi:https://doi.org/10.1108/jed-10-2019-0042

Butje, S., \& Tjondro, E. (2014). Pengaruh Karakter Eksekutif dan Koneksi Politik terhadap Tax Avoidance. Tax \& Acoounting Review, 4(2) , 1-9. Retrieved from https://media.neliti.com/media/publications/158338-ID-pengaruh-karakter-eksekutif-dankoneksi.pdf

Carolina, V., Natalia, M., \& Debbianita. (2014). Karakteristik Eksekutif terhadap Tax Avoidance dengan Leverage sebagai Variabel Intervening. Jurnal Keuangan dan Perbankan, 18(3), 409-419. doi:https://doi.org/10.26905/jkdp.v18i3.819

Chen, S., Chen, X., Cheng, Q., \& Shevlin, T. (2010). Are family firms more tax aggressive than non-family firms? Journal of Financial Economics, 95(1), 41-61. doi:http://dx.doi.org/10.1016/j.jfineco.2009.02.003

Chu, W. (2011). Family ownership and firm performance: Influence of family management, family control, and firm size. Asia Pacific Journal of Management, 28, 833-851. doi:10.1007/s10490-009-9180-1

Desai, M. A., \& Dharmapala, D. (2006). Corporate tax avoidance and high-powered incentives. Journal of Financial Economics, 79(1), 145-179. doi:https://doi.org/10.1016/j.jfineco.2005.02.002

Ding, S., Quc, C. J., \& Wu, Z. (2015). Corporate risk-taking: Exploring the effects of government affiliation and executives' incentives. Journal of Business Research, 68(6); 1196-1204. doi:https://doi.org/10.1016/j.jbusres.2014.11.014

Faccio, M., Masulis, R. W., \& McConnell, J. J. (2005). Political Connections and Corporate Bailouts. Journal of Finance, 61(6), 2597-2635. doi:https://doi.org/10.1111/j.1540-6261.2006.01000.x

Fisman, R. (2001). Estimating the Value of Political Connections. American Economic Review, 91(4), 1095-1102. doi:https://doi.org/10.1257/AER.91.4.1095

Friana, H. (2019, Juli 7). DJP Dalami Dugaan Penghindaran Pajak PT Adaro Energy Baca selengkapnya di artikel "DJP Dalami Dugaan Penghindaran Pajak PT Adaro Energy", https://tirto.id/edKk. Retrieved from Tirto.id: https://irto.id/djp-dalamidugaan-penghindaran-pajak-pt-adaro-energy-edKk

Gaaya, S., Lakhal, N., \& Lakhal, F. (2017). Does family ownership reduce corporate tax avoidance? The moderating effect of audit quality. Managerial Auditing Journal, 32(7), 731-744. doi:https://doi.org/10.1108/MAJ-02-2017-1530.

Haque, F., Arun, T., \& Kirkpatrick, C. (2011). The political economy of corporate governance in developing economies: The case of Bangladesh. Research in International Business and Finance, 25(2), 169-182. doi:10.1016/j.ribaf.2011.01.001

Hidayati, W., \& Diyanty, V. (2018). Pengaruh moderasi koneksi politik terhadap kepemilikan keluarga dan agresivitas pajak. Jurnal Akuntansi dan Auditing Indonesia, 27(1), 46-60. doi:https://doi.org/10.20885/jaai.vol22.iss1.art5

Hillman, A. J. (2005). Politicians on the Board of Directors: Do Connections Affect the Bottom Line? Journal of Management, 31(3), 464-481. doi:https://doi.org/10.1177/0149206304272187

Hilman, A., Waithers, M., \& Collins, B. (2009). Resource Dependence Theory: A Review. Journal of Management, 35(6), 14041427. doi:https://doi.org/10.1177/0149206309343469

Jensen, M. C., \& Meckling, W. H. (1976). Theory of the firm: Managerial behavior, agency costs and ownership structure Author links open overlay panel. Journal of Financial Economics, 3(4), 305-360. doi:https://doi.org/10.1016/0304-405X(76)90026$\mathrm{X}$

Jian, M., Li, W., \& Zhang, H. (2012). How does state ownership affect tax avoidance? Evidence from China. Seminar School of Accountancy. Singapore Management University. $\quad$ Retrieved from https://pdfs.semanticscholar.org/8670/e333e536f4717b8574721f75ddf96a08b06b.pdf

Kartana, I. W., \& Wulandari, N. G. (2018). Pengaruh Karakter Eksekutif, Karakteristik Perusahaan dan Corporate Governance Terhadap Tax Avoidance. Jurnal Krisna: Kumpulan Riset Akuntansi, 10(1), 1-13. http://dx.doi.org/10.22225/kr.10.1.708.113

Kelvin, A. (2019, July 26). Miris! Ternyata Tax Ratio Indonesia Terendah di Asia Pasifik. Retrieved from CNBC Indonesia: https://www.cnbcindonesia.com/news/20190726094730-4-87743/miris-ternyata-tax-ratio-indonesia-terendah-di-asiapasifik

Kim, C., \& Zhang, L. (2015). Corporate Political Connections and Tax Aggressiveness. Contemporary Accounting Research, 33(1), 78-114. doi:https://doi.org/10.1111/1911-3846.12150

Kovermann, J., \& Wendt, M. (2019). Tax avoidance in family firms: Evidence from large private firms. Journal of Contemporary Accounting \& Economics, 15(2), 145-157. https://doi.org/10.1016/j.jcae.2019.04.003

La Porta, R., Lopez-De-Silanes, F., \& Shleifer, A. (2002). Corporate Ownership Around the World. The Journal of Finance, 54(2), 471-517. :https://doi.org/10.1111/0022-1082.00115

Lestari, G. A., \& Putri, I. A. (2017). Pengaruh Corporate Governance, Koneksi Politik, dan Leverage terhadap Penghindaran Pajak. E-Jurnal Akuntansi Udayana, 18(3), 2028-2054. $\quad$ Retrieved from https://ojs.unud.ac.id/index.php/Akuntansi/article/view/25562/18038

Low, A. (2008). Managerial Risk-Taking Behavior and Equity-Based Compensation. Fisher College of Business Working Paper. 2006-03-003, pp. 1-42. Nanyang Technological University - Division of Banking \& Finance. doi:10.2139/ssrn.934857

Maharani, W., \& Juliarto, A. (2019). Pengaruh Kepemilikan Keluarga terhadap Tax Avoidance dengan Kualitas Audit sebagai Variabel Moderating. Diponegoro Journal of Accounting, $\quad 8(4), \quad 1-10$. doi:https://ejournal3.undip.ac.id/index.php/accounting/article/view/25659/22832 
Mirza, S. S., Safdar, R., Yu, Y., \& Gulzar, M. A. (2019). Managerial Empowerment and Firm Risk-Taking. Sage Journal, 9(2), 113. https://doi.org/10.1177/2158244019856963

Novita, N. (2016). Executives Characters, Gender and Tax Avoidance: A Study on Manufacturing Companies in Indonesia. Advances in Economics, Business and Management Research, 15, 92-95. https://doi.org/10.2991/gcbme-16.2016.15

Peng, M. W., \& Luo, Y. (2000). Managerial Ties and Firm Performance in a Transition Economy: The Nature of a Micro-Macro Link. The Academy of Management Journal, 43(3), 486-501. https://doi.org/10.5465/1556406

Pitaloka, S., \& Merkusiawati, N. K. (2019). Pengaruh Profitabilitas, Leverage, Komite Audit, dan Karakter Eksekutif Terhadap Tax Avoidance. E-Jurnal Akuntansi, 27(2), 1202-1230. https://doi.org/10.24843/EJA.2019.v27.i02.p14

Pranoto, B. A., \& Widagdo, A. K. (2016). Pengaruh Koneksi Politik Dan Corporate Governance Terhadap Tax Aggressiveness. Seminar Nasional dan The 3rd Call for Syariah Paper. Solo: Syariah Paper Accounting FEB UMS. Retrieved from https://publikasiilmiah.ums.ac.id/bitstream/handle/11617/7310/44\%20\%20Bayu\%20Agung\%20Pranoto.pdf?sequence=1\&i sAllowed=y.

Republik Indonesia. (2008). Undang-Undang Nomor 36 Tahun 2008 tentang Pajak Penghasilan. Jakarta: Sekretariat Negara. Retrieved from https://jdih.esdm.go.id/peraturan/UU\%20No.\%2036\%20Thn\%202008.pdf

Republik Indonesia. (2016). Peraturan Kementerian Keuangan Republik Indonesia Nomor 213 Tahun 2016 tentang Jenis Dokumen dan/atau Informasi Tambahan Yang Wajib Disimpan oleh Wajib Pajak yang Melakukan Transaksi dengan Para Pihak yang Mempunyai Hubungan Istimewa, Menimbang Dan Tata. Jakarta: Kementerian Keuangan Republik Indonesia. Retrieved from https://jdih.kemenkeu.go.id/fullText/2016/213 PMK.03 2016Per.pdf

Republik Indonesia. (2020). Peraturan Otoritas Jasa Keuangan Republik Indonesia Nomor 42 Tahun 2020 tentang Transaksi Afiliasi Dan Transaksi Benturan Kepentingan. jakarta: Otoritas Jasa Keuangan Republik Indonesia. Retrieved from https://ojk.go.id/id/regulasi/Documents/Pages/Transaksi-Afiliasi-dan-Transaksi-Benturan-Kepentingan/POJK\%20422020.pdf

Rusydi, M. K., \& Martani, D. (2014). Pengaruh Struktur Kepemilikan terhadap Aggressive Tax Avoidance. Simposium Nasional Akuntansi XVII. Malang. Retrieved from https://staff.blog.ui.ac.id/martani/files/2016/05/BF-B2c2-9-Pengaruh-StrukturKepemilikan...-Dwi-Martani.pdf.

Sari, D. K., \& Martani, D. (2010). Ownership Characteristics, Corporate Governance, and Tax Aggressiveness. The 3rd International Accounting Conference \& The 2nd Doctoral Colloquium. Bali. Retrieved from https://www.researchgate.net/profile/DewiSari-

26/publication/349199732_Ownership_Characteristics_Corporate_Governance_and_Tax_Aggressiveness/links/6024db234 585158939973e2e/Ownership-Characteristics-Corporate-Governance-and-Tax-Aggressiveness.pdf

Siregar, B. (2011). Kebijakan Dividen pada Perusahaan yang Dikendalikan oleh Pemegang Saham Pengendali Jurnal Akuntansi Manajemen, Sekolah Tinggi Ilmu Ekonomi Yayasan Keluarga Pahlawan Negara. Jurnal Akuntansi dan Manajemen, 22(3), 257-275. https://doi.org/10.24002/modus.v33i1.4066

Supadmi, Sutrisno T, Saraswati, E., \& Purnomosidhi, B. (2019). he Effect Of Related Party Transactions On Firm Performance : The Moderating Role Of Political Connection In Indonesian Banking. Business: Theory and Pracitce, 20, 81-92. https://doi.org/10.3846/btp.2019.08

Wirawan, I. G., \& Sukartha, I. M. (2018). Pengaruh Kepemilikan Keluarga dan Ukuran Perusahaan Pada Agresivitas Pajak dengan Corporate Governance Sebagai Variabel Pemoderasi. E-Jurnal Akuntansi Universitas Udayana, 23(1), 595-625. https://doi.org/10.24843/EJA.2018.v23.i01.p23

Wong, W.-Y., \& Hooy, C.-W. (2018). Do types of political connection affect firm performance differently? Pacific-Basin Finance Journal, 15, 297-317. https://doi.org/10.1016/j.pacfin.2018.08.009

Wu, W., Wu, C., Zhou, C., \& Wu, J. (2012). Political connections, tax benefits and firm performance: Evidence from China. Journal of Accounting and Public Policy, 31(3), 277-300. https://doi.org/10.1016/j.jaccpubpol.2011.10.005

Zhang, H., Jian, M., \& Li, W. (2012). How does state ownership affect tax avoidance ? Evidence from China. Associate Professor Nanyang Technological University (pp. 13-18). Singapore : School of Accountancy.

Publisher's Note: SSBFNET stays neutral with regard to jurisdictional claims in published maps and institutional affiliations.

\section{(c) (i)}

(C) 2021 by the authors. Licensee SSBFNET, Istanbul, Turkey. This article is an open access article distributed under the terms and conditions of the Creative Commons Attribution (CC BY) license (http://creativecommons.org/licenses/by/4.0/).

International Journal of Research in Business and Social Science (2147-4478) by SSBFNET is licensed under a Creative Commons Attribution 4.0 International License. 